\title{
Peranan Badan Permusyawaratan Desa dalam Penyelenggaraan Pemerintahan di Desa
}

\author{
Firman, Firman \\ Sekolah Tinggi Ilmu Hukum Lamaddukelleng, Sengkang \\ ${ }^{\Omega}$ Surel Koresponden: firmankuruseng132@gmail.com
}

\begin{abstract}
:
This study aims to determine and obtain data regarding the implementation of the main tasks and functions of the Village Consultative Body in the administration of government, and obtain data on the factors that influence the implementation of the main tasks and functions of the Village Consultative Body in the administration of government in Mattirowalie Village, Majauleng District, Wajo Regency. The research method uses data collection techniques through, observation, interviews, and documentation. The data obtained from the research results are processed using qualitative analysis to find out and obtain data regarding the implementation of the main tasks and functions of the Village Consultative Body in the administration of government and obtain data on what factors influence the implementation of the main tasks and functions of the Village Consultative Body in the administration of government. . The results of this study indicate that the implementation of the main tasks of the BPD in the administration of government has not been fully carried out optimally because only three main tasks are carried out namely accommodating and channelling the aspirations of the community, forming a village head election committee and the process of discussion and stipulation of village regulations together with the village head, out of six the main tasks that have been determined by the Government Regulation on Villages. the factors that influence the implementation of the main tasks and supervisory functions are influenced by two factors, namely the driving factor which includes community support or participation, and a good cooperative relationship between the Village Consultative Body and the Village Government. Whereas the second factor is the inhibiting factor which includes the lack of benefits provided to the members involved, facilities and infrastructure, lack of Human Resources to fill membership and the existence of a society that is either pro or contra to each decision made.

Keywords: consultation; village institutions; village government;
\end{abstract}

\begin{abstract}
Abstrak:
Penelitian ini bertujuan untuk mengetahui dan memperoleh data mengenai pelakanaan tugas pokok dan fungsi Badan Permusyawaratan Desa dalam penyelenggaraan pemerintahan, dan memperoleh data mengenai faktorfaktor yang mempengaruhi pelaksanaan tugas pokok dan fungsi Badan Permusyawaratan Desa dalam penyelenggaraan pemerintahan di Desa Mattirowalie Kecamatan Majauleng Kabupaten Wajo. Metode penelitian menggunakan teknik pengumpulan data melalui, observasi, wawancara, dan dokumentasi. Data yang telah diperoleh dari hasil penelitian diolah dengan menggunakan analisis kualitatif untuk mengetahui dan memperoleh data mengenai pelakanaan tugas pokok dan fungsi Badan Permusyawaratan Desa dalam penyelenggaraan pemerintahan dan memperoleh data mengenai faktor-faktor apa yang mempengaruhi pelaksanaan tugas pokok dan fungsi Badan Permusyawaratan Desa dalam penyelenggaraan pemerintahan. Hasil penelitian ini menunjukkan bahwa pelaksanaan tugas pokok BPD dalam
\end{abstract}


penyelenggaraan pemerintahan belum sepenuhnya dilakukan secara optimal karena hanya tiga tugas pokok yang dilaksanakan yaitu menampung dan menyalurkan aspirasi masyarakat, membentuk panitia pemilihan kepala Desa dan proses pembahasan dan penetapan peraturan desa bersama dengan kepala desa, dari enam tugas pokok yang telah ditetapkan Peraturan Pemerintah tentang Desa. faktor-faktor yang mempengaruhi pelaksanaan tugas pokok dan fungsi pengawasan dipengaruhi oleh dua faktor yaitu faktor pendorong yang meliputi dukungan atau partisipasi masyarakat, dan hubungan kerjasama yang baik antara Badan Permusyawaratan Desa dengan Pemerintah Desa. Sedangkan faktor yang kedua yaitu faktor penghambat yang meliputi kurangnya tunjangan yang diberikan kepada para anggota yang terlibat, sarana dan prasarana, kurangnya Sumber Daya Manusia yang mengisi keanggotaan serta adanya masyarakat yang pro maupun kontra terhadap setiap keputusan yang ditetapkan.

Kata Kunci: permusyawaratan; lembaga desa; pemerintahan desa;

Submit : 08-03-2020

Accepted : 11-04-2020

Doi: https://doi.org/10.56087/aijih.v23i1.35

\section{PENDAHULUAN}

Desa adalah sebuah entitas sosial yang memiliki tradisi atau pranata sosial dan kelengkapan budaya asli serta merupakan sebuah sistem sosial yang kemudian berkembang menjadi pemerintahan yang demokratis. Dalam sistem pemerintahan Negara Republik Indonesia, daerah indonesia dibagi atas daerah-daerah besar dan daerah kecil dengan bentuk dan susunan tingkatan pemerintahan terendah adalah Desa. Demokrasi pemerintahan Desa yang merupakan sub sistem penyelenggaraan pemerintah yang bersifat Otonom, dan berwenang mengatur dan mengurus kepentingan masyarakat terhadap perkembangan dan perubahan yang terjadi dalam masyarakat setempat. ${ }^{1}$

Berdasarkan kerangka otonomi daerah, salah satu komponen yang masih perlu dikembangkan adalah wilayah pedesaan. Eksistensi desa memiliki arti penting dalam proses pembangunan pemerintahan dan kemasyarakatan, untuk mewujudkan kemandirian pelaksanaan pembangunan yang berbasis pada wilayah pedesaan, artinya pembangunan pedesaan merupakan bagian integral dari pembangunan nasional yang bersifat menyeluruh. Agar program pemerintah berjalan efektif maka perlu adanya kepemimpinan aparatur Desa dalam mengelola atau mengarahkan

\footnotetext{
1 Yustika Ahmad Erani. (2015). Pembangunan dan pemberdayaan masyarakat Desa. cetakan pertama. Jakarta Selatan: Kementrian Desa, Pembangunan Daerah Tertinggal, Dan Transmigrasi RI 2015. hal, 69.
} 
masyarakat dengan tujuan berpartisipasi dalam pembangunan dan pemberdayaan masyarakat.

Untuk memperkuat dasar-dasar operasional pemerintahan Desa, pemerintah kemudian mengeluarkan Peraturan Pemerintah (PP) No. 43 Tahun 2014 tentang peraturan pelaksanaan Undang-undang no. 6 tahun 2014 tentang desa. Peraturan pemerintah ini melengkapi peraturan sebelumnya dengan menegaskan kewenangan desa.

Pembentukan Badan Permusyawaratan Desa (BPD) atau yang disebut nama lain adalah lembaga yang melakukan fungsi pemerintahan yang anggotanya merupakan wakil dari penduduk Desa berdasarkan keterwakilan wilayah dan ditetapkan secara demokratis untuk mengatur kepentingan masyarakat. Dengan demikian, pengisian anggota BPD dapat diproses melalui pemilihan secara langsung dan atau melalui musyawarah perwakilan. Hal ini dapat disesuaikan dengan kebutuhan dan kesepakatan masyarakat di Desa masing-masing.

BPD sebagai lembaga legislasi dan wadah yang berfungsi untuk menampung dan menyalurkan aspirasi masyarakat. Pada hakikatnya lembaga ini adalah mitra kerja pemerintah Desa yang memiliki kedudukan yang sejajar dalam menyelenggarakan urusan pemerintahan. BPDdapat membuat Rancangan Peraturan Desa yang secara bersama-sama Pemerintah Desa ditetapkan menjadi Peraturan Desa. Dalam hal ini, BPD sebagai lembaga pengawasan memiliki kewajiban untuk melakukan kontrol terhadap implementasi peraturan Desa serta anggaran pendapatan dan belanja Desa (APBDes).

Pembahasan mengenai BPD dalam Undang-Undang (UU No.32 Tahun 2004), pasal 209 dinyatakan bahwa BPD berfungsi menetapakan peraturan Desa bersama Kepala Desa, menampung dan menyalurkan aspirasi masyarakat.Demikian juga dengan masa jabatan BPD, mereka hanya bisa menjabat paling banyak 2 (dua) kali masa jabatan. Dari penjelasan di atas BPD hanya mempunyai 2 (dua) fungsi saja sebagaimana yang dijelaskan pasal 209. Berbeda dengan Undang-undang yang berlaku sekarang yaitu UU RI Nomor 6 Tahun 2014yang terdapat dalam (pasal 55) dijelaskan bahwa BPD mempunyai 3 (tiga) fungsi yaitu membahas dan menyepakati 
rancangan peraturan Desa bersama kepala Desa, ${ }^{2}$ menampung dan menyalurkan aspirasi masyarakat Desa, serta melakukan pengawasan kinerja Kepala Desa. Demikian juga BPD bisa menjabat paling banyak tiga kali masa jabatan, baik secara berturut turut maupun tidak berturut-turut.

Berlanjut pada hubungan antara Kepala Desa dan BPD. Jika sebelumnya Undangundang nomor 32 tahun 2004 tidak memberikan legitimasi kepada BPD untuk melakukan pengawasan terhadap pelaksanaan pemerintahan Kepala Desa, hal ini berbeda dengan Undang-Undang RI Nomor 06 Tahun 2014 yang memberikan legitimasi untuk itu. Pengaturannya lebih lanjut didasarkan pada peraturan pemerintah.

Sehubungan dengan itu, pelaksanaan fungsi Pemerintah Desa yang efektif mutlak diperlukan. ${ }^{3}$ Pemerintah Desa merupakan lembaga yang memiliki peran dan potensi yang cukup besar dalam membangun dan mengelola pemerintahan di desa. ${ }^{4}$ Pemerintah Desa selaku eksekutif di desa, berperan aktif dalam menentukan kebijakan maupun pelaksanaan pembangunan di desa. Selain itu, Pemerintah Desa harus mampu membangun kemitraan, baik denganBPD, pihak swasta maupun masyarakat itu sendiri. ${ }^{5}$

Fenomenanya dalam kondisi realitas, meskipun telah diamanahkan oleh UndangUndang RI Nomor 6 Tahun 2014, lembagaBPDdi Desa Mattirowalie Kecamatan Majauleng Kabupaten Wajo belum sepenuhnya melaksanakan tugas pokoknya. Selain itu BPD juga perlu memberikan fungsi pengawasan yang kuat kepada kepala Desa dalam menjalankan roda pemerintahan di Desa Mattirowalie Kecamatan majauleng Kabupaten Wajo. Agar dapat meminimalisir terjadinya penyimpangan terhadap pelaksanaan peraturan Desa dan pemnimpangan terhadap APBDes. Olehnya artikel ini merumuskan 2 hal dan mempertanyakannya, yaitu: bagaimana pelaksanaan tugas pokok dan fungsi pengawasan Badan Permusyawaratan Desa dalam penyelenggaraan pemerintahan di Desa Mattirowalie Kecamatan Majauleng Kabupaten Wajo, dan faktor-faktor apa yang mempengaruhi pelaksanaan tugas

\footnotetext{
${ }^{2}$ Huda Ni'matul. (2015). Hukum Pemerintahan Desa.Cetakan Pertama. Malang: Setara Press. hal, 73

3 Widaja. HAW. (2014), Otonomi desa. Cetakan ketujuh, Jakarta, Rajawali Pers. hal, 93

${ }^{4}$ Santoso Purwo, (2003). Pembaharuan Desa Seacara Partisipatif. Cetakan Pertama, Yogyakarta: Pustaka Pelajar, hal, 142.

5 Sarman. (2011). Pemerintahan Daerah Di Indonesia. Jakarta: Rineka Cipta. hal, 59
} 
pokok dan fungsi pengawasan Badan Permusyawaratan Desa dalam penyelenggaraan pemerintahan di Desa Mattirowalie Kecamatan Majauleng Kabupaten Wajo.

\section{METODE}

Pendekatan penelitian mempunyai peranan yang sangat penting dalam suatu penelitian. Pendekatan yang adalah pendekatan kualitatif dengan alasan bahwa pendekatan kualitatif lebih mudah disesuaikan apabila dihadapkan pada kenyataan dilapangan karena pendekatan kualitatif bersifat dinamis. Pendekatan kualitatif adalah metode penelitian yang digunakan untuk meneliti pada kondisi obyek yang alamiah dimana peneliti merupakan instrument kunci. Penelitian kualitatif ini memahami fenomena-fenomena sosial dari sudut pandang partisipan. Penelitian kualitatif lebih menekankan makna dari generalisasi. Dalam penelitian ini menggunakan jenis penelitian deskriptif yang merupakan salah satu strategi dalam sebuah penelitian kualitatif. Studi kasus merupakan strategi penelitian dimana didalamnya peneliti menyelidiki secara cermat suatu program, peristiwa, aktivitas, proses, atau sekelompok individu. Kasus-kasus dibatasi oleh waktu dan aktivitas, dan peneliti mengumpulkan informasi secara lengkap dengan menggunakan berbagai prosedur pengumpulan data berdasarkan waktu yang telah ditentukan. Penelitian ini mempunyai tujuan yaitu mengetahui secara langsung Peranan Badan Permusyawaratan Desa dalam penyelenggaraan pemerintahan di Desa Mattirowalie Kecamatan Majauleng Kabupaten Wajo.

Jenis data yang dikumpulkan dalam penelitian ini merupakan jawaban atas pertanyaan penelitian yang diajukan terhadap masalah yang dirumuskan dan pada tujuan yang telah ditetapkan mengenai pelaksanaan tugas pokok dan fungsi BPD dalam penyelenggaraan pemerintahan di Desa Mattirowalie Kecematan Majauleng Kabupaten Wajo dan faktor-faktor yang mempengaruhi pelaksanaan tugas pokok dan fungsi BPD dalam penyelenggaraan pemerintahan di Desa Mattirowalie Kecematan Majauleng Kabupaten Wajo. Sumber data dalam penelitian ini di peroleh melalui dua cara, yakni sebagai berikut : (1) Data primer, yaitu data yang diperoleh langsung dengan cara melakukan wawancara langsung kepada informan yang telah dipilih yaitu Ketua BPD, Wakil Ketua BPD, anggota BPD , Kepala Desa, Sekertaris 
Desa, Kepala Dusun, Tokoh Masyarakat yang mewakili setiap Dusun dan pengamatan secara langsung dilapangan pada objek penelitian. (2) Data sekunder, yaitu data diperoleh dari bahan bacaan, studi kepustakaan dan dokumentasi tentangPeranan Badan Permusyawaratan Desa dalam Penyelenggaraan Pemerintahan di Desa Mattirowalie Kecamatan MajaulengKabupaten Wajo.

\section{PEMBAHASAN}

Desa mattirowalie adalah salah satu desa dari 7 (tujuh) Desa/Kelurahan yang ada di Kecamatan MajaulengKabupaten Wajo. Desa mattirowalie terdiri atas 6 (enam) Dusun yakni Dusun Lapotta, Rumpiah Bua, Limpo majang, Telle Dan Lappadare. Desa Mattirowalie adalah desa agraris. Selanjutnya gambaran tentang sejarah Desa Mattirowalie adalah sebagai berikut: Desa mattirowalie adalah sebuah desa hasil pemakaran yang dulunya bergabung dengan Kelurahan Lompo Riaja.Namun karena desakan masyarakat dan persetujuan dari anggota DPRD Kabupaten Wajo akhirnya dimekarkan pada tahun 1994, Dimekarkan dengan nama desa mattirowalie dan kepala desanya bernama andi. Andi Aris, walaupun pada waktu itu masih dalam tahap desa persiapan. Pada tahun 1995 desa mattirowalie Menjadi desa definitif dan kepala desa masih Andi Aris sampai pada tahun 1999, Setelah melakukan pemilihan langsung kepala desa tahun 1999, akhirnya terpilih kembali sebagai kepala desa definitif periode 1999-2008 yaitu Andi. ARIS. Kemudian Pemilihan Kepala desa dilakukan kembali pada tahun 2008, dan yang terpilihsebagai kepala desa yaitu andi BAKRI sampai periode 2014 Dengan habisnya masa jabatan kepala desa di tahun 2014 selanjutnya untuk sementara kepala desa di jabat oleh Dra. Andi CAella sampai sekarang.

Keadaan Geografis Desa memiliki batas-batas wilayah:

- Sebelah Timur : Desa Bonto Penno

- Sebelah Utara : Kelurahan Lompo Majang

- Sebelah Barat : Desa Kading

- Sebelah Selatan : Desa Botto Tanre

Luas wilayah desa mattirowalie sekitar 2,718 Ha. Sebagian besar lokasi di desa mattirowalie adalah tanah persawahan, dan selebihnya adalah lahan perkebunan dan perumahan. Ada juga sebagian kecil penduduk yang berternak. Adapun Visi dan 
Misi Desa Mattirowalie adalah: adalah suatu gambaran ideal tentang keadaan masa depan yang diinginkan dengan melihat potengsi dan kebutuhan desa. Penyusunan Visi desa mattirowalie dilakukan dengan pendekatan partisipatif, melibatkan pihakpihak yang berkepentingan di desa seperti pemerintah desa, BPD, tokoh masyarakat, tokoh agama, tokoh perempuan, tokoh pemuda dan masyarakat desa pada umumnya. Berdasarkan hasil musyawarah bersama maka ditetapkan visi Desa Mattirowalie adalah:' 'Terwujudnya masyarakat desa yang maju dan makmur didukung oleh pertanian yang unggul dan sarana prasaranatransportasi yang memadai." Misinya selain penyusunan Visi juga ditetapkan misi-misi yang memuat sesuatu pernyataan yang harus dilaksanakan oleh Desa agar Visi desa dapat tercapai. Pernyataan visi ini dijabarkan ke dalam misi agar dapat dioperasionalkan dan dikerjakan. Sebagaimana penyusunan visi, misi pun dalam penyusunannya menggunakan pendekatan partisipatif dan dengan pertimbangan potengsi dan kebutuhan Desa Mattirowalie. Sebagaimana proses yang dilakukan maka misi Desa Mattirowalie adalah :

1. Meningkatkan hasil pertanian.

2. Meningkatkan kualitas sumber daya manusia disegala bidang.

3. Meningkatkan sarana dan prasarana transportasi.

4. Meningkatkan pendapatan masyarakat.

Pelaksanaan tugas pokok dan fungsi pengawasan BPD dalam penyelenggaraan pemerintahan di Desa Mattirowalie Kecamatan Majauleng Kabupaten Wajo, berdasarkan hasil penelitian, terdapat tugas pokok dan fungsi Pengawasan BPD yang telah dilaksanakan di Desa Mattirowalie yaitu sebagai berikut :

1) Menampung dan menyalurkan aspirasi masyarakat

Berdasarkan wawancara dengan Bapak Munir bahwa, BPD merupakan wadah bagi aspirasi masyarakat desa.wadah aspirasi yang dimaksud disini yaitu sebagai tempat bagi masyarakat untuk menampung segala keluhankeluhannya dan kemudian menindaklanjuti aspirasi tersebut untuk disampaikan kepada instansi atau lembaga yang terkait. Banyak cara yang dilakukan untuk menampung segala keluhan-keluhan yang kemudian ditindaklanjuti yaitu dengan cara tertulis dan secara lisan. Cara tertulis misalnya masalah-masalah tersebut terkait dengan pembangunan dan kemajuan desa maka akan dibahas dan dibicarakan lebih lanjut dalam bentuk 
peraturan-peraturan desa, dan dengan cara lisan yaitu masyarakat menyampaikan aspirasinya langsung kepada BPD

Berdasarkan wawancara dengan Bapak Suyuti menambahkan bahwa, setelah aspirasi masyarakat desa ditampung, maka langkah selanjutnya adalah BPD menyalurkan aspirasi masyarakat tersebut dalam pertemuan-pertemuan yang diselenggarakan oleh BPD. Setelah memperoleh aspirasi dan kemudian membahasnya, BPD kemudian meneruskan dan menyampaikan sebagaimana maksud yang diharapkan oleh masyarakat. ${ }^{6}$ Namun pada kesempatan ini pihak pemerintah desa tetap diberi kesempatan untuk memberikan penjelasan atas aspirasi yang disampaikan oleh masyarakat.

2) Membentuk Panitia Pemilihan Kepala Desa

Berdasarkan wawancara dengan Bapak Munir bahwa, Sebelum diadakan Pemilihan Kepala Desa, BPD terlebih dahulu membentuk panitia Pemilihan Kepala Desa. Yang dimana keanggotaannya berasal dari Unsur Perangkat Desa, Pengurus Lembaga Kemasyarakatan, dan Tokoh masyarakat. Berdasarkan wawancara dengan Bapak Suyuti menambahkan bahwa, Dalam pemilihan kepala desa di desa ini, hal yang dilakukan oleh BPD terlebih dahulu yaitu membentuk panitia pemilihan, dimana panitia-panitia tersebut dapat berasal dari tokoh-tokoh masyarakat, unsur-unsur perangkat desa, maupun lembaga-lembaga kemasyarakatan yang ada di Desa, setelah itu anggota BPD berembuk dan berunding kemudian memustuskan siapa-siapa yang menjadi panitia pemilihan.

Adapun tugas dari panita pemilihan kepala desa yaitu :

a) melaksanakan semua kegiatan selama pencalonan kepala desa dan bertanggung jawab kepada BPD dengan cara melaporkan hasil pelaksanaan kegiatan mulai dari penjaringan bakal calon sampai dengan terpilih Kepala Desa.

b) Panitia pemilihan kepala desa, membuat semacam informasi atau sosialisasi di masyarakat bahwa akan dilaksanakannya Pemilihan

${ }^{6}$ Solekhan, Moch. MAP. (2014). Penyelenggaraan Pemerintahan Desa. Cetakan Pertama Malang: Setara Press. hal, 88 
Kepala Desa, kemudian panitia pemilihan melakukan pendataan dan pendaftaran Bakal Calon Kepala Desa.

c) Setelah itu, Bakal Calon Kepala Desa yang terpilih kemudian akan disaring melalui beberapa syarat-syarat yang telah ditentukan sebelumnya dan hasil penyaringan akan di tetapkan menjadi Calon Kepala Desa.

d) Calon Kepala Desa inilah yang nantinya akan diumumkan kepada masyarakat di tempat-tempat yang mudah dijangkau oleh masyarakat.

3) Proses pembahasan dan penetapan peraturan Desa bersama Kepala Desa

Berdasarkan wawancara dengan Bapak Munir yang mengatakan bahwa, Dalam merumuskan dan menetapkan peraturan desa, BPD bersama-sama dengan pemerintah Desa (Kepala Desa dan Perangkat Desa), melalui beberapa proses antara lain sebagai berikut:

a) Pemerintah Desa mengundang anggota BPD untuk menyampaikan maksudnya membentuk peraturan desa dengan menyampaikan pokokpokok peraturan desa yang diajukan.

b) Pemerintah Desa terlebih dahulu mengajukan rancangan peraturan desa kepada BPD .

c) BPD dan Kepala Dusun serta Tokoh-tokoh masyarakat memberikan masukan atau usulan untuk melengkapi atau menyempurnakan rancangan peraturan desa.

d) Ketua BPD menyampaikan usulan tersebut kepada pemerintah desa untuk diagendakan.

e) BPD mengadakan rapat dengan pemerintah desa kurang lebih satu sampai dua kali untuk memperoleh kesepakatan bersama.

Berdasarkan wawancara dengan Bapak Suyuti menambahkan bahwa, Setelah BPD dan Kepala Desa mengajukan rancangan Peraturan Desa kemudian akan dibahas bersama dalam rapat BPD dan setelah mengalami penambahan dan perubahan, kemudian rancangan Peraturan Desa tersebut disahkan dan disetujui serta ditetapkan sebagi Peraturan Desa. Dalam menetapkan peraturan desa, antara BPD dan Kepala Desa sama-sama memiliki peran yang sangat penting yaitu BPD 
menyutujui dikeluarkannya Peraturan Desa kemudian Kepala Desa yang Menetapkan Peraturan Desa tersebut.

Berdasarkan wawancara dengan Bapak Munir yang mengatakan bahwa, Setelah usulan-usulan tersebut dibahas dan dievaluasi kemudian dilakukan penetapan bersama dalam bentuk rancangan untuk selanjutnya dirumuskan dalam bentuk Peraturan Desa. Berdasarkan wawancara Bapak Muhammad Rizal yang menambahkan bahwa, Usulan-usulan yang telah ditampung tersebut berasal atau bersumber dari Pemerintah Desa dan BPD serta Kepala Dusun dan tokoh-tokoh masyarakat yang ikut serta dalam proses pembahasan dan penetapan Peraturan Desa yang dimana usulan tersebut dapat menjadi dasar atau patokan dalam menjalankan Pemerintahan Desa. Meskipun gagasan atau usulan-usulan yang sudah ditampung lebih banyak berasal dari pemerintah desa. ${ }^{7}$ Dari uraian diatas dapat dilihat bahwa pelaksanaan tugas pokok BPD tidak sepenuhnya dilaksanakan. Hal ini dapat dilihat bahwa hanya ada 3 (tiga) tugas pokok yang dilaksanakan dari 6 (enam) tugas pokok yang telah ditetapkan pada PP No 72 Tahun 2005.

\section{Faktor-Faktor yang Mempengaruhi Pelaksanaan Tugas Pokok Dan Fungsi} Pengawasan BPD di Desa Mattirowalie Kecamatan Majauleng Kabupaten Wajo

Berdasarkan hasil penelitian yang telah dilakukan di Desa mattirowalie, pelaksanaan tugas pokok dan fungsi pengawasan BPD dipengaruhi beberapa faktor yaitu:

\section{a. Faktor Pendorong}

\section{1) Dukungan/partisipasi masyarakat terhadap BPD}

Berdasarkan wawancara dengan Bapak Munir yang mengatakan bahwa Masyarakat merupakan faktor penentu keberhasilan BPD dalam melaksanakan fungsinya, besarnya dukungan, sambutan dan penghargaan dari masyarakat kepada BPD menjadikan BPD lebih mempunyai ruang ge rak untuk dapat melaksanakan fungsinya.Dukungan dari masyarakat tidak hanya pada banyaknya aspirasi yang masuk juga dari pelaksanaan suatu Perdes.Kemauan dan semangat dari masyarakatlah yang Gaji ataupun tunjangan yang diberikan hanya berasal dari dana operasional desa yang

${ }^{7}$ Rusdiyanta Syahrial Syarbaini, (2009). Dasar-Dasar Sosiologi.Edisi Pertama, Yogyakarta: Graha Ilmu, hal 101 
diberikan oleh pemerintah desa dan pemberiannya tidak menentu setiap bulan.

\section{2) Sarana dan prasarana}

Berdasarkan wawancara dengan Bapak Munir yang mengatakan bahwa, Untuk menunjang kinerja anggota BPD, yang dibutuhkan yaitu sarana dan prasarana seperti tempat atau kantor sebagai pusat kegiatan. Tidak adanya tempat khusus bagi BPD sebagai pusat kegiatan administrasif layaknya lembaga legislatif lainnya, fasilitas operasional juga menjadi faktor berpengaruh demi kelancaran kinerja BPD.Meskipun BPD hanya bekerja dalam skala desa, hal ini juga menjadi faktor berpengaruh. Berdasarkan wawancara dengan Bapak Muhammad Risal yang mengatakan bahwa, Sarana dan prasarana yang ada di desa mattirowalie masih kurang memadai seperti tempat atau kantor BPD yang belum ada, seharusnya BPD mempunyai ruang kantor tersendiri dan tidak bergabung kepada kantor kepala desa sebagai mitra kerjanya. Oleh karenanya dalam menjalankan tugas dan fungsi pengawasan BPD akan terhambat.

3) Kurangnya SDM yang mengisi keanggotaan BPD Berdasarkan wawancara dengan Bapak Suyuti yang mengatakan bahwa, Salah satu faktor penghambat pelaksanaan tugas pokok dan fungsi pengawasan BPD di desa mattirowalie adalah kurangnya SDM yang masih rendah dimana sebagian

Terdapat pula faktor-faktor yang mempengaruhi pelaksanaan tugas pokok dan fungsi pengawasan BPD dalam penyelenggaraan pemerintahan di Desa Mattirowalie Kecamatan Majauleng Kabupaten Wajo.

\section{a. Faktor pendorong}

Adapun faktor pendorong pelaksanaan tugas pokok dan fungsi pengawasan BPD dalam penyelenggaraan pemerintahan di Desa Mattirowalie Kecamatan MajaulengKabupaten Wajo yaitu Dukungan/partisipasi masyarakat terhadap BPD, dan Hubungan Kerjasama yang baik antara BPD dengan Pemerintah Desa. Partisipasi masyarakat baik dalam bentuk aspirasi maupun dalam pelaksanaan suatu keputusan serta dalam mengawasi pelaksanaan peraturan desa yang dibuat bersama berperan besar dalam pelaksanaan tugas dan fungsi pengawasan BPD. Besarnya dukungan dari 
masyarakat kepada BPD juga dapat memberikan ruang gerak untuk dapat melaksanakan tugas dan pengawasannya. ${ }^{8}$

Selain itu hubungan kerjasama yang baik antara BPD dengan pemerintah Desayang merupakan salah satu faktor yang berpengaruh dalam pelaksaanaan tugas pokok dan fungsi pengawasan BPD, hubungan yang harmonis sebagai unsur yang bermitra dalam penyelenggaraan pemerintahan desa, BPD dan Pemerintah Desa selalu menyadari adanya kedudukan yang sejajar dimana posisi dan fungsi keduanya saling mendukung untuk terselenggaranya pemerintahan desa

\section{b. Faktor penghambat}

Tidak dapat dipungkiri bahwa pelaksanaan tugas pokok dan fungsi pengawasan BPD tidak selalu berjalan lancar.Adapun faktor penghambat dalam pelaksanaan tugas pokok dan fungsi pengawasan BPD yaitu, kurangnya tunjangan yang diberikan kepada anggota BPD Sarana dan prasarana, Kurangnya SDM yang mengisi keanggotaan BPD serta Adanya masyarakat yang pro maupun kontra terhadap setiap keputusan yang ditetapkan.

\section{KESIMPULAN DAN SARAN}

Pelaksanaan tugas pokok BPD Desa Mattirowalie sepenuhnya belum terlaksana hal ini dapat dilihat tugas pokok yang telah dilaksankan oleh BPD yaitu menampung dan menyalurkan aspirasi masyarakat, membentuk panitia pemilihan kepala Desa, proses pembahasan dan penetapan peraturan Desa bersama dengan Kepala Desa. Mengenai fungsi Pengawasan yang dilakukan oleh BPD telah dilaksanakan dengan baik sehingga dapat meminimalisir terjadinya penyimpangan terhadap APBDes. Pelaksanaan tugas pokok dan fungsi pengawasan BPD dalam penyelenggaraan pemerintahan di Desa Mattirowalie Kecamatan Majauleng Kabupaten Wajo dipengaruhi oleh dua faktor yaitu faktor pendorong dan faktor penghambat.Faktor pendorong yaitu Dukungan/partisipasi masyarakat terhadap BPD, dan hubungan kerjasama yang baik antara BPD dengan Pemerintah Desa. Sedangkan faktor penghambat yaitu kurangnya tunjangan yang diberikan kepada anggota BPD, sarana

\footnotetext{
${ }^{8}$ Nurcholishanif. (2011). Pertumbuhan Dan Penyelenggaraan Pemerintahan Desa. Erlangga. hal, 63
} 
dan prasarana, kurangnya SDM yang mengisi keanggotaan BPD serta adanya masyarakat yang pro maupun kontra terhadap setiap keputusan yang ditetapkan.

Adapun saran- saran yang dapat diajukan dalam artikel ini, yaitu: BPD diharapkan dapat lebih memahami dan mengetahui seluruh kubutuhan dari masyarakat dalam hal pembangunan agar tidak ada lagi perpedaan pendapat dalam proses menentukan pembangunan di desa mattirowalie, dan melaksanakan tugas pokok yang belum dilaksanakan serta perlunya kesadaran bagi anggota BPD agar lebih sering hadir di kantor desa untuk melaksankan kewajibannya dan lebih mempermudah dalam berkoordinasi dengan Kepala Desa.

Kepada Pemerintah Desa, dikarenakan masih banyak program pembangunan yang belum dilaksanakan, maka kerjasama antara Kepala Desa dengan BPD yang berlangsung dengan baik perlu dipertahankan untuk pelaksanaan pembangunan yang belum berjalan. Dengan mempertahankan kerjasama, diharapkan program pembangunan yang belum terlaksana dapat diselesaikan dengan baik sesuai dengan apa yang sudah direncanakan.

Kepada masyarakat diharapkan agar dapat memberikan dukungan/partisipasi kepada BPD dalam melaksanakan tugas pokok dan fungsi pengawasannya .serta masyarakat harus sadar dengan pembangunan yang direncanakan oleh pemerintah desa karena pembangunan tersebut semata-mata untuk masyarakat itu sendiri.

\section{REFERENSI}

Huda Ni'matul. (2015). Hukum Pemerintahan Desa.Cetakan Pertama. Malang: Setara Press.

Nurcholishanif. (2011). Pertumbuhan Dan Penyelenggaraan Pemerintahan Desa. Erlangga.

Mukti, M. (2018). Politik Hukum Pembentukan Peraturan Daerah Tentang Anggaran Pendapatan Dan Belanja Daerah. Al-Ishlah: Jurnal Ilmiah Hukum, 20(2), 75-84.

Rusdiyanta Syahrial Syarbaini, (2009). Dasar-Dasar Sosiologi.Edisi Pertama, Yogyakarta: Graha Ilmu 
Solekhan, Moch. MAP. (2014). Penyelenggaraan Pemerintahan Desa. Cetakan Pertama Malang: Setara Press.

Sarman. (2011). Pemerintahan Daerah Di Indonesia. Jakarta: Rineka Cipta.

Santoso Purwo, (2003). Pembaharuan Desa Seacara Partisipatif. Cetakan Pertama, Yogyakarta: Pustaka Pelajar

Widaja. HAW. (2014), Otonomi desa. Cetakan ketujuh, Jakarta, Rajawali Pers.

Yustika Ahmad Erani. (2015). Pembangunan dan pemberdayaan masyarakat Desa. cetakan pertama. Jakarta Selatan: Kementrian Desa, Pembangunan Daerah Tertinggal, Dan Transmigrasi RI 2015.

Undang-Undang Nomor 23 Tahun 2014 tentang Pemerintahan Daerah, perubahan atas Undang-Undang Nomor 32 Tahun 2004 Tentang Pemerintahan Daerah

Undang-Undang Nomor 6 Tahun 2014 Tentang Undang-Undang Desa

Peraturan Pemerintah No. 43 Tahun 2014 tentang Peraturan Pelaksanaan UndangUndang No 6 Tahun 2014 sebagaimana perubahan atas Peraturan Pemerintah No. 72 Tahun 2005 tentang Pedoman Umum Pengaturan Mengenai Desa 